\title{
"IMPACT OF PRODUCT INNOVATION ON THE FINANCIAL PERFORMANCE OF THE SELECTED ORGANIZATIONS: A STUDY IN INDIAN CONTEXT"
}

\author{
Dr. Naveen Nandal, \\ Assistant Professor, Sushant University, Gurugram \\ Dr. Aarushi Kataria, \\ Assistant Professor, Bharati Vidyapeeth University, New Delhi
}

\author{
Nisha Nandal, \\ Research Scholar, Ansal University, Gurugram
}

\author{
Ms. Neetu Jora, \\ Assistant Professor, Sushant University, Gurugram
}

\begin{abstract}
:
The purpose of this research is to analyze the determinants of product innovation and its impact on the financial performance of the organizations. Specifically, the study examines the impact of intelligence generation, intelligence dissemination, productprocess innovation, marketing support of the product, quality, Dependability/ Delivery, Technology selection, Flexibility on the financial performance of the automobile companies. The models of product innovation provided the theoretical framework for the research. The model of product-process innovation provides the basis for further research. The first concept explains the link between organizations surroundings and its innovation targets (Utterback JM 1974, 1975) (Miller \& Friesen, 1982)(Milling, 1996) whereas the second concept explains the connection between firm's performance level i.e. innovative performance, financial performance, organizational performance and marketing performance and its innovation types i.e. product innovation, process innovation, organizational innovation and marketing innovation (Abernathy \& Townseed, 1975) (Abernathy \& Utterback, June/July 1978) (Gunday, et al., 2011). From these concepts evolved this study i.e. to evaluate the impact of product innovation on the financial performance of the organizations.
\end{abstract}

Article Received: 18 October 2020, Revised: 3 November 2020, Accepted: 24 December 2020

\section{INTRODUCTION}

During modern decades increasing ecological concerns have become a well-built encouragement to creative thinking. Ecological system will exert huge weight on production industries, which will augment in the upcoming time, enabling a more surviving globe for coming generation. The automobile industry is one of several industries causing ecological pollution where cars have a important impact on all stages of the life cycle; manufacturing, use, reusing and dumping (Orsato and Wells, 2007). This business also continues to cultivate. The number of cars in worldwide use will amplify in close future, mainly due to growing command in budding countries. As an instance, the amount of cars sold in China has enlarged by over $25 \%$ per annum in the past ten years, building China the world's biggest car marketplace. In 2012, the international car fleet conceded the one billion score. As a result of the increasing car market, the automotive industry records for $27 \%$ of $\mathrm{CO} 2$ releases in the world (WWF, 2013). Automakers have also shown an escalating awareness of the ecological impact of their products as environmental rules and market demands for ecologically less disparaging cars have augmented. The centre on reducing $\mathrm{CO} 2$ has become a well-built driver in the growth of not only less ecologically vicious cars, such as Electric Vehicles (EV) and Hybrid Electric Vehicles (HEV), but also of mass-reduction wayouts. 
Product innovation makes the healthy environment inside the firm that enhances the growth, improves the financial returns and superior brand image ( $\underline{\mathrm{Liu}}$ et al. (2002) (Walker, June, 2004) . Studies have revealed that good experience within the firm is linked with growth of novel information and facts, which is significant element for organization results and uniqueness (Wheelwright \& Clark, 1992)(Wong, 2014). Hence, there is need to address the issue of how to create product innovation in the organizations. The empirical research on the product innovation is limited both in volume and scope; especially in Indian Context. Thus, there is a need to understand the product innovation and its impact on the financial performance of the organizations. The automobile business involves two distinct businesses: (i) the automotive business; and (ii) the auto segment business. The automotive business further has three sub-parts: (a) twowheelers; (b) three-wheelers; and (c) fourwheelers (passenger and commercial vehicles). While the history of India's growth in the economy is known in the last two decades, it is usually termed as a services-leading concept. Although, some production fields have played a major act in this industrial development and the automobile industry is important among them. The automobile industry's addition is not only in terms of sales revenues, incomes, taxes to be paid and jobs, but more particularly in productionprocess superiority, efficient enhancements and state of the art. This change has been vision through the sectors in the economic transportation, usability transportation, cars and automotive parts business. The automobile industry is the pillar of global economy, a main driver of macro economic growth, stability and technological advancement in developed and developing countries, covering many adjacent industries (Kearney, A.T, 2013). Firms adopted innovation approach since longtime, but very little published literature is available on the experiences of firms. Most companies are using the basic innovation approach without categorizing the types of innovation. However, the implementation strategies and managerial commitment to innovation approach vary from company to company. This study deals with the determinants of product innovation and its impact on the financial performance of the organizations.

\section{LITERATURE REVIEW}

Product innovation means dissimilar equipment to diverse group. It can be opening of a new product into a market place for the first time (Kanter, 1982)(Kanter, 2006 Nov). Few people regarded innovation as the upgradings in the old products (Andreasen \& Hein, 1985). Although, changes in the products for betterment is taken as product innovation in many corporate houses. Product Innovation may be distinct as the expansion of novel goods, alterations in features of recognized goods, or make use of novel resources or mechanism in the production of recognized goods.

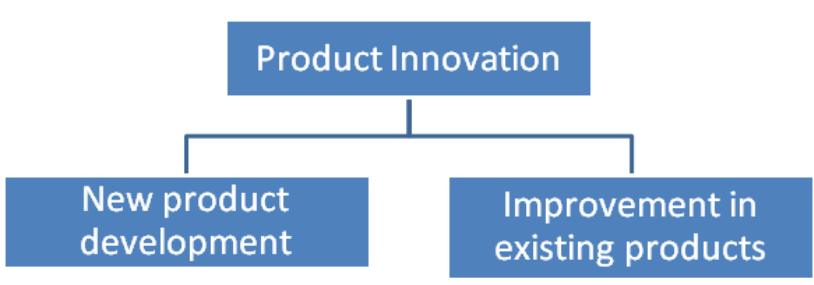

Figure 2.1 represents the product innovation in two categories of innovation:

For the business to exist in the aggressive market, it is relevant to pioneer new-fangled goods and services (Cahill, 1996). On the other hand, it is established that over 80 percent of novel goods be unsuccessful. Further, even thriving opening do not constantly results in top-level development.

\section{Showing Constructs, Measurement of Variables and Authors}




\begin{tabular}{|c|c|c|}
\hline Constructs & $\begin{array}{l}\text { Measurement Variables for } \\
\text { Investigation in the Study }\end{array}$ & Author(s) \\
\hline \multirow[t]{4}{*}{ Intelligence Generation } & $\begin{array}{l}\text { a) Process of intelligence } \\
\text { generation }\end{array}$ & $\begin{array}{l}\text { Nonaka and Toyama, 2002; Wiig } \\
\text {,1997 ; Ramachandran and Ray, } \\
2006\end{array}$ \\
\hline & $\begin{array}{l}\text { b) Design of new products, } \\
\text { services or systems. }\end{array}$ & \\
\hline & $\begin{array}{l}\text { c) Capability to generate } \\
\text { intelligence and utilize it }\end{array}$ & \\
\hline & $\begin{array}{l}\text { d) Capability to engage } \\
\text { employees in innovative } \\
\text { activities. }\end{array}$ & \\
\hline \multirow[t]{4}{*}{$\begin{array}{l}\text { Intelligence } \\
\text { Dissemination }\end{array}$} & a) Interaction among employees & $\begin{array}{l}\text { Ruggles, 1996; Frances and } \\
\text { Sandberg, 2000; Nonaka and } \\
\text { Takeuchi, 1995; Sheshadri et al., } \\
2003\end{array}$ \\
\hline & $\begin{array}{l}\text { b) Availability of appropriate } \\
\text { infrastructure and processes }\end{array}$ & \\
\hline & c) Familiarity with colleagues & \\
\hline & $\begin{array}{l}\text { d) Identifying and designing } \\
\text { intelligence dissemination } \\
\text { processes. }\end{array}$ & \\
\hline \multirow[t]{4}{*}{ Technology selection } & a) Selection of leading strategy & $\begin{array}{l}\text { Shengbin Hao, Bo Yu, 2011; M. } \\
\text { Torkkeli and M. Tuominen,2002; } \\
\text { S. B. Hao and B. Y,2009 ; G. M. } \\
\text { Bao and J. Yang,2004;J. } \\
\text { Morone,1989; D. Cetindamar, R. } \\
\text { Phaal and D. Probert ,2009; D. } \\
\text { Cetindamar, R. Phaal and D. } \\
\text { Probert ,2009 }\end{array}$ \\
\hline & $\begin{array}{l}\text { b) High emphasis on R\&D } \\
\text { activities }\end{array}$ & \\
\hline & $\begin{array}{l}\text { c) Selection of advanced } \\
\text { technology in industry. }\end{array}$ & \\
\hline & d) Develops new products totally & \\
\hline
\end{tabular}




\begin{tabular}{|c|c|c|}
\hline Constructs & $\begin{array}{l}\text { Measurement Variables for } \\
\text { Investigation in the Study }\end{array}$ & Author(s) \\
\hline \multirow[t]{2}{*}{$\begin{array}{l}\text { Marketing support of } \\
\text { the product }\end{array}$} & $\begin{array}{l}\text { a) Renews the design of the } \\
\text { current and new products }\end{array}$ & $\begin{array}{l}\text { Hauser, et al., 2006; Henderson, } \\
\text { 1994; Pelham, 1997; Wang and } \\
\text { Wei, 2005; Lhuillery, 2014; Li, } \\
\text { 2000; Buzzel and Gale, 1987; } \\
\text { Venkatraman and Prescott, } \\
\text { 1990, Wang and Wei, } 2005\end{array}$ \\
\hline & $\begin{array}{l}\text { b) Renews the distribution } \\
\text { channels without changing } \\
\text { the logistics processes. }\end{array}$ & \\
\hline \multirow[t]{2}{*}{$\begin{array}{l}\text { Product-Process } \\
\text { Innovation }\end{array}$} & $\begin{array}{l}\text { a) Determines and eliminates } \\
\text { non-value adding activities in } \\
\text { production processes. }\end{array}$ & $\begin{array}{l}\text { Ettile, 1995; Fruin, 1998; } \\
\text { Galbraith, 1982; Meeus \& } \\
\text { Edquist, 2006; Damanpour, } \\
\text { Gopalakrishnan 1999; Pisano, } \\
1997\end{array}$ \\
\hline & $\begin{array}{l}\text { b) Decrease manufacturing cost } \\
\text { in components and materials } \\
\text { of current products. }\end{array}$ & \\
\hline \multirow[t]{4}{*}{ Financial performance } & $\begin{array}{l}\text { a) Increase in the ratio of return } \\
\text { on sales }\end{array}$ & $\begin{array}{l}\text { Aktan \& Bulut, 2008; } \\
\text { Andriessen, 2007; } \\
\text { Venkatraman and Ramanujam } \\
\text { 1986; Fis \& Cetindamar, 2009; } \\
\text { Floyd \& Woolridge, 1990; } \\
\text { Gatignon \& Xuereb, 1997; } \\
\text { Gopalakrishnan, 2000; Gunday, } \\
\text { et al., 2011; Heshmati \& Loof, } \\
\text { 2006; Lumpkin \& Dess, 2001; } \\
\text { Malerba \& Marengo, 1995; } \\
\text { Mankin, } 2007\end{array}$ \\
\hline & $\begin{array}{l}\text { b) Increase in the ratio of return } \\
\text { on assets }\end{array}$ & \\
\hline & $\begin{array}{l}\text { c) Increase in the general } \\
\text { profitability of the firm }\end{array}$ & \\
\hline & $\begin{array}{l}\text { d) Increase in the cash flow of } \\
\text { the firm. }\end{array}$ & \\
\hline
\end{tabular}

\section{RESEARCH METHODOLOGY}

The researcher used quota sampling dividing into the Delhi/ NCR amongst four automobile companies i.e. the four of them are market leaders as per their market share and in each of these areas purposive sampling is used for the purpose of survey. It is a sampling techniques in which the sample is obtained by selecting convenient population units. For the purpose of the study, primary data was collected with the help of a welldrafted Questionnaire given to Top and middle executives in the automobile organizations $(\mathrm{N}=423)$. Measurements for the model's constructs were adopted from the literature and in 
some cases adapted for the study. Cronbach Alpha was used to evaluate the internal consistency of the scale items and Structural Equation Modelling was used to test the proposed hypotheses. Results suggest that determinants of product innovation influence the financial performance of the organizations. Implications for automobile organizations i.e. main leaders of the sector are presented along with future directions for research academics and industry practitioners.

\section{Proposed Model}

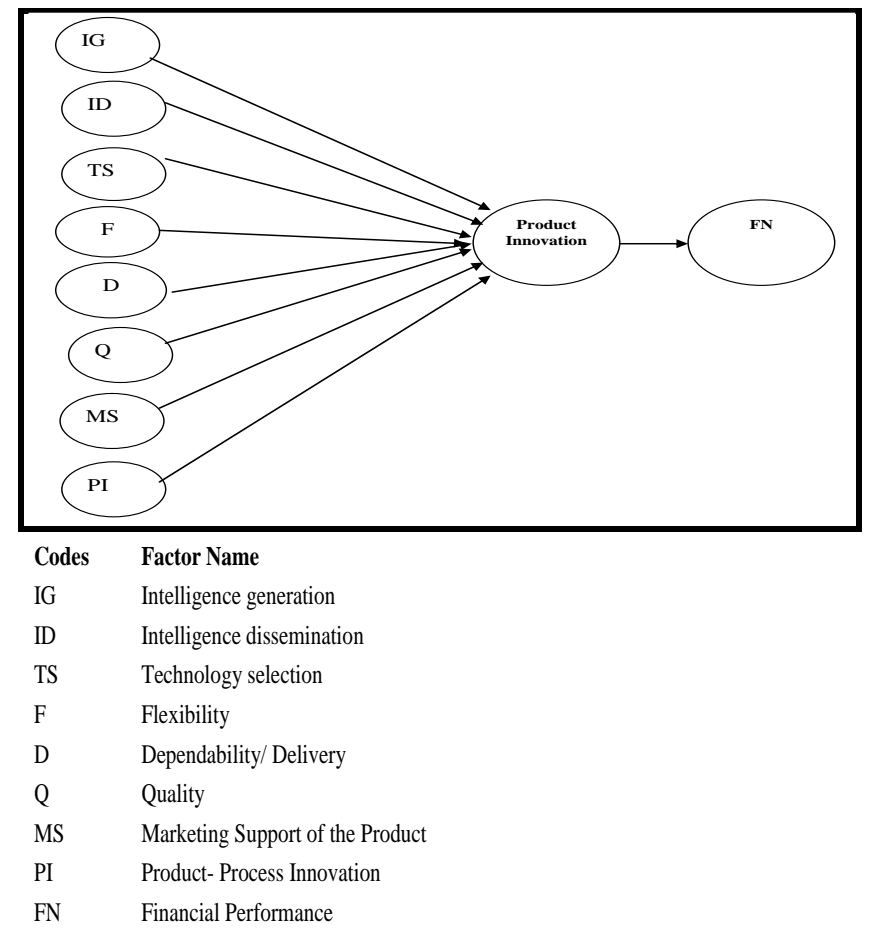

\section{DATA ANALYSIS AND RESULTS}

Reliability is the degree to which a group of measurable variables would give similar outcomes if information gathering were duplicated (Malhotra, 2007) and is tested by considering the ratio of organized change in a scale. Measuring the Cronbach Alpha coefficient of a scale is the main generally accepted barometer of internal consistency (Pallant, 2007), with the fair Cronbach Alpha coefficient being over 0.7 (Hair et al. 2010). A figure of less than 0.7 is taken to state uncontented internal consistency reliability (Malhotra, 2007). Cronbach's Alpha is taken in this study to test internal consistency reliability of the 32 measurable variables of the questionnaire.

\begin{tabular}{|c|c|c|c|}
\hline Constructs & Items & $\begin{array}{c}\text { Cronbach Alpha } \\
\text { Coefficient }\end{array}$ & Reliability Results \\
\hline Intelligence generation & 4 & 0.811 & Good \\
\hline Intelligence Dissemination & 4 & 0.751 & Good \\
\hline Technology Selection & 5 & 0.784 & Good \\
\hline Flexibility & 4 & 0.811 & Good \\
\hline Dependability/ Delivery & 5 & 0.781 & Good \\
\hline Quality & 2 & 0.736 & Good \\
\hline $\begin{array}{l}\text { Marketing support of the } \\
\text { product }\end{array}$ & 2 & 0.708 & Good \\
\hline Product-Process Innovation & 2 & 0.715 & Good \\
\hline Financial Performance & 4 & 0.819 & Good \\
\hline Overall & 32 & 0.893 & Good \\
\hline
\end{tabular}

The Cronbach Alpha coefficient of the 'Impact of product innovation on the financial performance of the organizations' measurement scale of the research, as shown in Table above is 0.893 . Because this value is above the required 0.7 Cronbach Alpha fair, the measurable variables used have a contented internal consistency and can be termed as reliable statistically.

\section{FACTOR ANALYSIS}

Factor Analysis is a data condensing statistical method that permits simplifying the interrelation linkages between numbers of repeated items. Factor analysis permits analysts to reduce a big group of items or measurement variables down into a small, more organized- number of constructs or factors. After the information has been gathered from 100 respondents, Factor Analysis was taken to obtain the general constructs from among the variables based on the linkages between them (DeCoster, 1998). The total variable Explained box was recommending that it obtains one construct detailed for $65.73 \%$ of the variance of the link between items. There are just nine constructs, each having Eigen value greater than 1 . The Eigen values for nine constructs were $8.557,2.259,1.964,1.692,1.489,1.426,1.334$, 1.205 and 1.109 , correspondingly. 


\section{Total Variance Explained}

\begin{tabular}{|c|c|c|c|c|c|c|c|c|c|}
\hline \multicolumn{10}{|c|}{ Total Variance Explained } \\
\hline \multirow[t]{2}{*}{ Factor } & \multicolumn{3}{|c|}{ Initial Eigenvalues } & \multicolumn{3}{|c|}{$\begin{array}{c}\text { Extraction Sums of Squared } \\
\text { Loadings }\end{array}$} & \multicolumn{3}{|c|}{$\begin{array}{c}\text { Rotation Sums of Squared } \\
\text { Loadings }\end{array}$} \\
\hline & Total & $\begin{array}{c}\% \text { of } \\
\text { Variance }\end{array}$ & $\begin{array}{c}\text { Cumulative } \\
\%\end{array}$ & Total & $\begin{array}{c}\% \text { of } \\
\text { Variance }\end{array}$ & $\begin{array}{c}\text { Cumulative } \\
\%\end{array}$ & Total & $\begin{array}{c}\% \text { of } \\
\text { Variance }\end{array}$ & $\begin{array}{c}\text { Cumulative } \\
\%\end{array}$ \\
\hline 1 & 8.557 & 26.742 & 26.742 & 8.557 & 26.742 & 26.742 & 3.156 & 9.862 & 9.862 \\
\hline 2 & 2.259 & 7.058 & 33.800 & 2.259 & 7.058 & 33.800 & 3.127 & 9.772 & 19.635 \\
\hline 3 & 1.964 & 6.139 & 39.939 & 1.964 & 6.139 & 39.939 & 2.952 & 9.224 & 28.858 \\
\hline 4 & 1.692 & 5.286 & 45.225 & 1.692 & 5.286 & 45.225 & 2.593 & 8.104 & 36.963 \\
\hline 5 & 1.489 & 4.652 & 49.877 & 1.489 & 4.652 & 49.877 & 2.515 & 7.858 & 44.821 \\
\hline 6 & 1.426 & 4.457 & 54.333 & 1.426 & 4.457 & 54.333 & 2.381 & 7.440 & 52.261 \\
\hline 7 & 1.334 & 4.167 & 58.501 & 1.334 & 4.167 & 58.501 & 1.604 & 5.012 & 57.273 \\
\hline 8 & 1.205 & 3.765 & 62.265 & 1.205 & 3.765 & 62.265 & 1.411 & 4.410 & 61.683 \\
\hline 9 & 1.109 & 3.465 & 65.730 & 1.109 & 3.465 & 65.730 & 1.295 & 4.047 & 65.730 \\
\hline 10 & .981 & 3.065 & 68.795 & & & & & & \\
\hline
\end{tabular}

Extraction Method: Principal Axis Factoring.

\section{Construct Validity}

'Construct validity leads to the extent to which assumption can accurately be made from the functionalities in your research to the theoretical factors on which those functions were dependent (Trochim, 2006). In other words, it means whether the scale measures what it claims to measure. Construct validity consists of convergent validity, discriminant validity and nomological validity (Malhotra, 2010). For the present research, convergent validity and discriminant validity will be considered. Both these validities should be considered jointly in order to get the proof for construct validity (Trochim, 2006).

\section{Convergent Validity}

Convergent validity shows the degree to which the measures of a construct are positively related to each other (Malhotra, 2010). Convergent validity is determined by comparing Cronbach alpha of the construct with Average Variance Explained by the measures (Hair et.al, 2010). The Convergent validity is achieved if: 1) Cronbach Alpha coefficient> Average Variance Explained 2) Cronbach Alpha co-efficient is greater than 0.7 3)
Average Variance Explained $>0.5$. The below table shows the validity and reliability of all the dimensions. As the value of Cronbach alpha is above .07 for all dimensions this shows all dimensions have good reliability and internal consistency. AVE is also above 0.4 which is threshold value. Therefore, the nine constructs met the norms of convergent validity.

\section{Discriminant Validity}

Discriminant validity shows the extent to which the constructs differ from each other. It is assessed by comparing the squared correlation (R2) of the paired constructs with the AVEs of each construct (Fornell \& Larcker, 1981). For this, Maximum of the two correlation coefficients is taken and squared. This is called Maximum Shared Variance (MSV). Discriminant validity can be said to be satisfactory if MSV of a pair of constructs is less than the AVE for each corresponding construct (Hair et.al, 2010). As the MSE is below AVE and ASV is below AVE it shows that the constructs differ from each other. Therefore, the nine constructs met the norms of discriminant validity. 


\begin{tabular}{l|c|c|c|c|}
\hline \multicolumn{1}{c|}{ Factors } & $\begin{array}{c}\text { Cronbach } \\
\text { Alpha co- } \\
\text { efficient }\end{array}$ & $\begin{array}{c}\text { Average } \\
\text { Variance } \\
\text { Explained }\end{array}$ & $\begin{array}{l}\text { Average } \\
\text { Variance } \\
\text { Explained }\end{array}$ & $\begin{array}{l}\text { Maximum } \\
\text { Shared Variance }\end{array}$ \\
\hline $\begin{array}{l}\text { Dependability/ } \\
\text { Delivery }\end{array}$ & 0.781 & 0.574 & 0.574 & 0.36 \\
\hline $\begin{array}{l}\text { Intelligence } \\
\text { Generation }\end{array}$ & 0.811 & 0.497 & 0.497 & 0.31 \\
\hline $\begin{array}{l}\text { Flexibility } \\
\text { Technology }\end{array}$ & 0.811 & 0.577 & 0.577 & 0.38 \\
$\begin{array}{l}\text { Selection } \\
\text { Intelligence } \\
\text { Dissemination }\end{array}$ & 0.784 & 0.550 & 0.550 & 0.37 \\
\hline Quality & 0.736 & 0.504 & 0.504 & 0.25 \\
\hline $\begin{array}{l}\text { Product- } \\
\text { Process } \\
\text { Innovation }\end{array}$ & 0.715 & 0.512 & 0.512 & 0.40 \\
\hline $\begin{array}{l}\text { Marketing } \\
\text { support of the } \\
\text { product }\end{array}$ & 0.708 & 0.541 & 0.584 & 0.28 \\
\hline $\begin{array}{l}\text { Financial } \\
\text { Performance }\end{array}$ & 0.819 & 0.595 & 0.595 & 0.43 \\
\hline
\end{tabular}

\section{Confirmatory Factor Analysis}

CFA is first conducted at the individual construct's level to explore its dimensionality, reliability, convergent, and discriminant validity.
Then, CFA is further conducted at the overall proposed conceptual model level to analyze the fit of the sample model with the population model.

\section{Model Fit Indices of each Construct}

\begin{tabular}{|c|c|c|c|c|c|}
\hline \multirow[b]{2}{*}{ Constructs } & \multicolumn{5}{|c|}{ MODEL FIT INDICES } \\
\hline & CFI & GFI & RMSEA & P-CLOSE & CMIN/df \\
\hline Dependability/ Delivery & 0.998 & 0.997 & 0.033 & 0.517 & 1.536 \\
\hline Technology selection & 0.992 & 0.968 & 0.056 & 0.062 & 4.200 \\
\hline Financial performance & 0.998 & 0.989 & 0.038 & 0.851 & 1.966 \\
\hline Intelligence Generation & 0.989 & 0.975 & 0.052 & 0.382 & 2.810 \\
\hline Flexibility & 0.999 & 0.997 & 0.059 & 0.305 & 3.336 \\
\hline $\begin{array}{l}\text { Intelligence } \\
\text { dissemination }\end{array}$ & 0.997 & 0.987 & 0.052 & 0.079 & 4.509 \\
\hline Quality & 0.998 & 0.989 & 0.038 & 0.851 & 1.966 \\
\hline $\begin{array}{l}\text { Linking Product-process } \\
\text { Innovation }\end{array}$ & 0.989 & 0.975 & 0.052 & 0.382 & 2.810 \\
\hline $\begin{array}{l}\text { Marketing Support of the } \\
\text { product }\end{array}$ & 0.992 & 0.97 & 0.059 & 0.078 & 3.305 \\
\hline
\end{tabular}

\section{Notes:}

1. CFI \& GFI value of 0.95 and above signifies good model fit (Byrne, 2013)

2. RMSEA value less than 0.05 is considered good, P-CLOSE value greater than 0.05 is acceptable and CMIN/df value between less than 3 is considered good but sometimes less than 5 is permissible ( $\mathrm{Hu}$ and Bentler,1999)

The table above shows the model fit indices of all constructs namely, IntelligenceDissemination, 
Intelligence Generation, Technology Selection, Quality, Flexibility, Dependability/ Delivery, Marketing support of the product and Linking product-process innovation. In case of Dependability/ Delivery, all indices values are above the cut-off level and imply a good model fit; the GFI and CFI value are above the cut-off point, RMSEA is close to cut-off point and PCLOSE is in acceptable range. CFI \& GFI are goodness of fit indices whereas RMSEA is badness of fit index, therefore, the lesser it is the better the model fit is. The CMIN/df value is also within acceptable range indicating a good model fit.

\section{OVERALL VALIDATED AND PROPOSED SEM MODEL}

A confirmatory factor analyses (CFA) was performed with Amos. All variables parcels loaded significantly onto their particular constructs (loadings moving from .63 to .72 on the product innovation scale and between .65 and .86 on the impact of financial performance scale). Even though the two factors are assumed as independent, they were permitted to inter-link. The regular correlation $(\mathrm{r}=.05)$ between the constructs though was not important, holding the independence of the two measurements. Chisquare value for the entire model fit was important, $\chi 2(416)=3669.903, p<.001$ recommending a deficiency of fit between the assumed model and the data. Although, due to the responsiveness of $\chi 2$ in big samples, other fit indices were tested (Kline, 1998).

\section{First order- SEM Model}

The model was made and revised for a good model fit. The predictions used for measuring the model fitness were Chi-square/degrees of freedom $(\chi \sqrt{ } / \mathrm{df})$ ratio, root mean-square error of approximation (RMSEA), Goodness of fit index (GFI), comparative fit index (CFI). The results are shown in the table below:

\section{MODEL FIT INDICES}

\begin{tabular}{|c|c|c|c|c|c|}
\hline & CFI & GFI & RMSEA & P-CLOSE & CMIN/df \\
\hline $\begin{array}{c}\text { SEM Initial } \\
\text { Model }\end{array}$ & 0.874 & .862 & .043 & 0.634 & 3.278 \\
\hline
\end{tabular}

(SEM) was used in this research to check proposed model and assumptions and used AMOS as the analysis instrument. For criterion estimation, maximum likelihood method was accepted. Measurement model and structural model test were taken to test fitness of the model. To test straight and implied relationships among the interested variables the researchers have taken a two-step procedure using confirmatory factor analysis and structural equation modeling (Anderson \&Gerbing, 1988). Amos has been taken to perform these analyses.

The proposed model was initially checked for the fitness. The prediction taken for measuring the model fitness were Chi-square/degrees of freedom $(\chi \sqrt{ } / \mathrm{df})$ ratio, root mean-square error of approximation (RMSEA), normed fit index (NFI), comparative fit index (CFI), Tuck Willis Index (TLI).

\section{Second order Confirmatory Model}

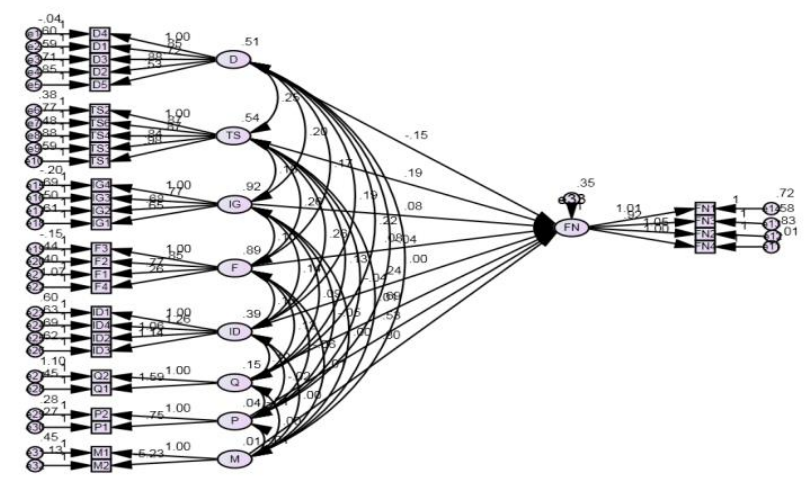

Figure 4.13: Showing the second order Confirmatory Model

The chi-square test of entire model fit is named variations in this result. Its figure is 3669.903 with 416 degrees of freedom, giving a probability value of less than .000 that a chi-square value this large or larger would be extracted by probability if the null hypothesis that the model fits the data is real.

The 416 degrees of freedom shows the level of over identification of the model. Since the probability value of the chi-square test is smaller than the .05 level used by conference, we would have dismissed the null hypothesis that the model 
fits the data. Although, due to the responsiveness of $\chi 2$ in large samples, other fit indices were assessed (Kline, 1998). Inspection of these indices represents acceptable model fit with TLI $=.811$, $\mathrm{CFI}=.842, \mathrm{RMSEA}=.079, \mathrm{NFI}=0.797$.

\section{Second Order-Structural Model}

Financial performance $(\mathrm{FN})$ is defined as the second order factor which is elaborating all variance and co-variance linked to the first order factor arrangement. It is significant to take specific note of the fact that financial performance
(FN) does not have its own group of measured barometers; instead, it is related impliedly indirectly to those measuring the lower order constructs. Initially, observe the availability of single-headed arrows coming from the secondorder construct $(\mathrm{FN})$ to each of the first order constructs (Dependability (D) to Marketing support of the product (M)). These regression paths show second-order factor loadings and all are independently predicted.

\section{showing Standardized Regression Weight Summary}

\begin{tabular}{|c|c|c|r|r|r|l|l|}
\hline $\begin{array}{c}\text { Financial } \\
\text { performance }\end{array}$ & $<---$ & Estimate & S.R. & C.R. & P & Label \\
\hline $\begin{array}{c}\text { Financial } \\
\text { performance }\end{array}$ & $<---$ & Intelligence Generation & 0.133 & 0.059 & 2.244 & $* * *$ & par_65 \\
\hline $\begin{array}{c}\text { Financial } \\
\text { performance }\end{array}$ & $<---$ & Flexibility & 0.256 & 0.041 & 6.196 & $* * *$ & par_66 \\
\hline $\begin{array}{c}\text { Financial } \\
\text { performance }\end{array}$ & $<---$ & Technology Selection & 0.087 & 0.068 & 1.293 & $* * *$ & par_67 \\
\hline $\begin{array}{c}\text { Financial } \\
\text { performance }\end{array}$ & $<---$ & $\begin{array}{c}\text { Intelligence } \\
\text { Dissemination }\end{array}$ & 0.181 & 0.088 & 2.047 & $* * *$ & par_68 \\
\hline $\begin{array}{c}\text { Financial } \\
\text { performance }\end{array}$ & $<---$ & Quality & 0.628 & 0.315 & 1.991 & $* * *$ & par_69 \\
\hline $\begin{array}{c}\text { Financial } \\
\text { performance }\end{array}$ & $<---$ & $\begin{array}{c}\text { Product-Process } \\
\text { Innovation }\end{array}$ & 0.496 & 0.573 & 0.866 & $* * *$ & par_70 \\
\hline $\begin{array}{c}\text { Financial } \\
\text { performance }\end{array}$ & $<---$ & $\begin{array}{c}\text { Marketing support of } \\
\text { the product }\end{array}$ & 0.639 & 0.461 & 1.385 & $* * *$ & par_71 \\
\hline
\end{tabular}

Co variances between factors were measured and taken as input for confirmatory factor analysis. Co variances, means and standard deviations of the averaged measures are shown in Table below. All the predicted co variances were statistically significant $(\rho<0.05)$. The path coefficients found in table of the path estimates are significant $(\mathrm{p} \leq$ 0.05). According to results, dependability, flexibility, marketing support of the product, quality, product-process innovation, technology selection, intelligence generation and intelligence dissemination has a considerable positive effect on financial performance

\section{CONCLUSION}

The major aim of this research was to investigate the important internal organizational determinants that prompt product innovation and made an instrument that measures these determinants. To achieve this objective, the research collected data from 423 managers in 4 organizations. Outcomes from the investigation can therefore assist to define internal organizational determinants phase of impacts and finalize the base for better environment to enhance entrepreneurial activities. The role of organizational factors for stimulating product innovation has been discussed. After identifying different organizational 
factors from literature, a discussion has been followed by an empirical study conducted to identify the impact of product innovation on financial performance. The outcomes of the research and their affects for further study and executives action have been stated in detail.

This study has established that in the context of the fast changing needs of the customers, the adoption of product innovation is very important. The presence of internal organizational drivers/factors is critical for financial outcomes. A product innovation model has been evolved, which may be used by organizations to assess the presence of necessary and critical internal factors for stimulating product innovation activities within the organization. This framework can further be enriched by subsequent studies. There are several factors reinforcing relationships once they have been established. In this study financial performance has been related to the components of product innovation and it has been found the product innovation has a positive impact on the financial performance. So the automobile sector cannot neglect the product innovation as it is very essential for the overall success of the organization. All the business earnestly works for improvement of the financial performance so; product innovation is one of the key element to improve the financial performance.

\section{BIBLIOGRAPHY:}

[1] Abernathy, J. W. \& Utterback, M. J., June/July 1978. Patterns of Innovation in Industry. Technology Review Vol. 80, No. 7 , pp. 40-47.

[2] Abernathy, W. \& Townseed, P., 1975. Technology, Productivity and Process change. Technol. forecasting \& Soc. Change 7 (4), pp. 379-396.

[3] Aktan, B. \& Bulut, C., 2008. Financial performance impacts of corporate entrepreneurship in emerging markets: A case of Turkey. European Journal of Economics, Finance and administrative Sciences, 12, pp. 69-79.
[4] Andreasen, M. \& Hein, L., 1985. Integrated Product Development. IFS Publications Ltd/ Springer Verlag, Bedford, UK/Berlin, Heidelberg.

[5] Andriessen, D., 2007. Designing and testing an OD intervention: reporting intellectual capital to develop organizations. The journal of applied behavioural Science, Vol. 43, No. 1, pp. 89-107.

[6] Bao, G. \& Yang, J., 2004. The role of technological Management in technological Innovation: Based on the enterprises in Zhejiang. Studies in science of science, Vol. 22, No.5, pp. 546-551.

[7] Boyer, K. \& Lewis, M., 2002. Competitive priorities: Investigating the need for tradeoffs in operations strategy. Production and operations management, 11(1), pp. 9-20.

[8] Cahill, D., 1996. Entrepreneurial orientation or pioneer advantage. Acad manage rev,21, pp. 603-605.

[9] Cetindamar, D., Phaal, R. \& Probert, D., 2009. Understanding technology management as a dynamic capability:A frame work for technology management activitites. Technovation, Vol. 29, No. 4, pp. 237-246.

[10] Damanpour, F. \& Gopalakrishnan, S., 1999. Organizational adaptation and innovation: The dynamicsof adopting Innovation types. The dynamics of Innovation, Spronger, Berlin, pp. 57-80.

[11] Ettile, J., 1995. Product-Process development integration in manufacturing. Management Science, Vol. 41, No.7, pp. 1224-1237.

[12] Fis, A. \& Cetindamar, D., 2009. The missing link between firm-level entrepreneurship and performance. 9th International Entrepreneurship Forum, Istanbul, pp. 1-12.

[13] Floyd, S. \& Woolridge, B., 1990. The strategy process, Middle Management Involvement and organizational 
performance. Strategic Management Journal, 13, pp. 53-242.

[14] Francis, D. \& Sandberg, W., 2000. Friendship within entrepreneurial teams and its association with team and venture performance. Entrepreneurship theory and practice, Volume 25(2), pp. 5-26.

[15] Fruin, W., 1998. Smart Card and product development strategies: A summary and propositions about their implementations. IEEE transactions on engineering Management, 40(3), pp. 224-235.

[16] Galbraith, J., 1982. Designing the innovating organization. Organizational Dynamics, Winter, pp. 5-25.

[17] Gatignon, H. \& Xuereb, J.-M., 1997. Strategic orientation of the firm and new firm performance. J Mark Res, 34, pp. 7790.

[18] Gopalakrishnan, S., 2000. Unraveling the links between dimensions of innovation and organizational performance. The journal of High Technology management research, 11(1), pp. 137-153.

[19] Gunday, G., Ulusoy, G., Kilic, K. \& Alpkan, L., 2011. Effects of innovation types on firm performance. International journal of production economics, pp. 662676.

[20] Gunday, G., Ulusoy, G., Kilic, K. \& Alpkan, L., 2011. Effects of innovation types on firm performance. International journal of production economics, pp. 662676.

[21] Hair, J. B. W. B. B. a. A. R., 2010. Multivariate data analysis. Prentice-Hall, Inc. Upper Saddle River, NJ, USA, Issue 7 th edition.

[22] Hao, S. \& Yu, B., 2009. Research on impact mechanism of technology strategy on technology innovation and organizational performance. Studies in Science of Science, Vol. 27, No. 8, pp. 1263-1270.
[23] Hauser, J., Tellis, G. \& Griffin, A., 2006.

Research on innovation: A review and agenda for marketing Science. Marketing science, 25(6), pp. 687-717.

[24] Henderson, R., 1994. Managing Innovation in the information age. Harvard business review, 72(1), pp. 100105.

[25] Heshmati, A. \& Loof, H., 2006. Sources of finance, $\quad R \& D$ investment and productivity: Correlation or casuality? ICFAI Journal of industrial Economics, 3(4), pp. 43-59.

[26] Kanter, R., 1982. Supportinginnovation and venture development in established companies. Journal of Business Venturing, 1, pp. 47-60.

[27] Kanter, R., 2006 Nov. Innovation: The classical Traps. Harvard Business Review , pp. 73-83.

[28] Lhuillery, S., 2014. Marketing and persistent innovation success. Economics of innovation and New Technology, 23(56), pp. 517-543.

[29] Lumpkin, G. \& Dess, G., 2001. Linking two dimensions of entrepreneurial orientation to firm performance: The Moderating role of environment and industry life cycle. Journal of Business Venturing, 16, pp. 429-451.

[30] Malerba, F. \& Marengo, L., 1995. Competence, innovative activities and economic performance in Italian HightECHNOLOGY fIRMS. International journal of Technology Management,vol. 10,No. 4, pp. 461-477.

[31] Mankin, E., 2007. Measuring Innovation performance. Research Technology Management, vol. 50(6).

[32] Meeus, M. \& Edquist, C., 2006. Introduction to part1: Product and process innovation. Oxford University press, pp. 23-37.

[33] Miller, D. \& Friesen, P., 1982. Innovation in conservative and entrepreneurial firms: 
Two models of strategic momentum. Strategic Management Journal,3, pp. 125.

[34] Milling, P., 1996. Modeling Innovation processes for decision support and management simulation. system dynamics review, Vol. 12, No.3, pp. 211-234.

[35] Morone, J., 1989. Strategic Use of Technology. California Management Review, Vol. 31, No.4, pp. 91-110.

[36] Nonaka, I. \& Toyama, R., 2002. A firm as a dialetic being: Toward the dynamic theoryof the firm. Industrial and corporate change, Volume 11, pp. 995-1109.

[37] Orsato, R. \& Wells, P., 2007. The automobile industry and sustainability. Journal of cleaner production, 15(11), pp. 989-993

[38] Pallant, J., 2007. SPSS survival manual: A step by step guide to data analysis using SPSS for windows (3rd edition). London: Open University press.

[39] Pisano, G., 1997. The development factory: Unlocking the potential of process Innovation. HBS Press, Boston, Mass.

[40] Ramachandran, K. \& Ray, S., 2006. Networking and resource strategies in new ventures: A study of information technology start-ups. Journal of entrepreneurship, p. 15(2).

[41] Ruggles, R., $1996 . \quad$ Knowledge Management tools. Heinemann: Boston, MA.

[42] Torkkeli, M. \& Tuominen, M., 2002. The contribution of technology selection to core competencies. International Journal of Production Economies, vol. 77, No. 3, pp. 271-284.

[43] Trochim, W. M. K., 2006. Introduction to Validity. Social Research Methods. www.socialresearchmethods.net/kb/introv al.php.

[44] Utterback, J., 1974. Innovation in industry and the diffusion of technology. Science 183, pp. 620-626.
[45] Venkatraman, N. \& Ramanujam, V., 1986. Measurement of business performance in strategy research: A comparison of approaches. The Academy of Management review, 11(4), pp. 801-814.

[46] Walker, R., June, 2004. Innovation and organizational performance: Evidence and a research agenda". Advanced institute of management research.

[47] Wheelwright, S. \& Clark, K., 1992. Revolutionizing product development. The free press, New York.

[48] Wiig, K., 1997. Knowledge management: An introduction and perspective. Journal of knowledge management, Volume 1(1), pp. 6-14.

[49] Wong, S., 2014. Impacts of environmental turbulence on entrepreneurialorientation and new product success. European journal of Innovation Management, Vol. 17 No. 2, pp. 229-249. 